\title{
IMPLEMENTASI OTOMASI LAYANAN PERPUSTAKAAN DENGAN SLIMS (SENAYAN LIBRARY AUTOMATION SYSTEM) DI PERPUSTAKAAN UNDIKSHA
}

\author{
Kadek Surya Mahedy \\ Fakultas Teknik Informatika, Universitas Pendidikan Ganesha \\ email: kadek.mahedy@gmail.com
}

\begin{abstract}
Abstrak
Perpustakaan sebagai pemberi layanan kepada pemakai atau pengunjung memerlukan metode-metode pelayanan yang bersifat cepat, mudah dan efisien. Layanan perpustakaan yang masih bersifat manual menimbulkan berbagai kendala dalam pemberian layanan seperti layanan bersifat lambat, sulitnya pencarian koleksi dan kurang akuratnya data yang diarsip. Kemajuan teknologi informasi dan komputer menawarkan peluang sangat besar untuk menunjang kelancaran tugas-tugas di berbagai bidang kehidupan termasuk di dalamnya bidang perpustakaan. Perpustakaan sebagai institusi pengelola informasi merupakan salah satu bidang penerapan teknologi informasi yang berkembang dengan pesat. Salah satu fitur yang dapat dikembangkan dalam bidang perpustakaan adalah pengembangan perpus takaan digital berbasis web. Pemanfaatan web site memberi kemudahan akan akses informasi yang lebih cepat baik dari dalam maupun dari luar perpustakaan.

Artikel ini merekomendasikan sebuah perangkat lunak perpustakaan digital berbasis open source yang diharapkan menjadi alternatif pemberian layanan untuk mengatasi kendala-kendala dalam akses informasi di perpustakaan, proses pelayanan perpustakaan, dan pengarsipan data yang dilakukan secara manual. Sistem ini penggunaannya mudah, data yang disimpan akurat dan mudah dimutakhirkan, serta informasi data anggota dan koleksi perpustakaan dapat diakses kapan saja diperlukan melalui internet. Sistem ini dibangun dengan model website menggunakan script PHP dan database menggunakan My SQL.
\end{abstract}

Kata kunci : perpustakaan, perpustakaan digital, web.

\begin{abstract}
Library as service giver to wearer or visitor need the service method having the character of quickly, easy to and efficient. Library service which still have the character of the manual generate various constraint in service gift like service have the character of tardy, its difficult seeking collect and less be its accurate data which archives. Progress of information technology and computer offer the opportunity very big to support the duties fluency in various life area inclusive of in it library area. Library as institution of information organizer represent one of area of adjusment of information technology expanding at full speed. One of fitur which can be developed in the field of library is digital library development base on the web. Exploiting of web site give the amenity will access the good quicker information from within and also from outside library.

This article yield a digital library software base on the opensource expected become the alternative of service gift to overcome the constraints in accessing information in library, process the library service, and data archives conducted in manual. This system its use easy to, data kept accurate and recent easy to, and also information of member data and collect the library can be accessed any time needed by internet. This system develop and builded with the model website use script PHP and database use the My SQL.
\end{abstract}

Keyword : library, digital library, web.

\section{PENDAHULUAN}

Penerapan Teknologi Informasi (TI) saat ini telah menyebar hampir di semua bidang tidak terkecuali di perpustakaan. Perpustakaan sebagai institusi yang bertugas mengelola bahan pustaka, baik berupa buku maupun bukan berupa buku (non book material) sehingga dapat digunakan sebagai sumber informasi oleh setiap pemakainya. Implementasi TI secara optimal sangat diperlukan dalam layanan perpustakaan. Karena sebagian besar 
pekerjaan-pekerjaan yang dilakukan di perpustakaan berupa layanan kepada pemakai, sehingga diperlukan metodemetode pelayanan yang bersifat cepat, mudah dan efisien. Layanan perpustakaan meliputi layanan sirkulasi, layanan refrensi dan layanan ruang baca (Bafadal, 2005:125). Mutu layanan perpustakaan dapat diukur dari dari kemampuan memberikan informasi bahan pustaka yang tepat dan kemampuan memberikan layanan yang cepat, efisien dan akurat kepada pemakainya.

Perpustakaan sebagai pemberi layanan kepada pemakai atau pengunjung memerlukan metode-metode pelayanan yang bersifat cepat, mudah, dan efisien. Perpustakaan selalu dituntut untuk memberikan layanan optimal kepada pengguna perpustakaan. Perpustakaan Universitas Pendidikan Ganesha (Undiksha) dalam memberikan layanan kepada pemustaka sudah memanfaatkan sistem informasi berbasis teknologi informasi. Sistem informasi yang diterapkan di Perpustakaan Undiksha menangani database buku, pembuatan kartu, layanan sirkulasi, layanan OPAC (Online Public Access Catalog) dan menangani denda keterlambatan buku. Sistem informasi yang diterapkan di Undiksha masih memiliki beberapa kelemahan, yaitu : dalam pemberian layanan sirkulasi kepada pemustaka masih mengalami kesulitan karena petugas harus memasukkan satu per satu kode buku dan memilih nomor inventaris buku yang dipinjam sehingga waktu pemberian layanan relatif lama. Dalam sistem keamanan koleksi juga masih lemah karena belum ada pendeteksi buku yang masuk dan keluar ruang koleksi buku. Uraian diatas memberikan gambaran bahwa sistem informasi yang diterapkan di Undiksha masih memiliki kelemahan dalam pemberian layanan kepada pemustaka.

Selama ini system informasi yang kita kenal bagi perpustakaan adalah cds/isis atau sipisis, dynix, simpus, siprus, openbiblio, koha, athenium, senayan, openisis, winisis dan sebagainya yang masing-masing memiliki keunggulan dan kelemahan masing-masing. Sedangkan untuk pengadaan system informasi itu sendiri ada yang didapatkan dari membeli dari pengembang software, membuat sendiri atau bahkan mengunduh dari internet yang bersifat gratis dan legal yang terbukti handal dan memiliki sarana komunikasi online. Bagi perpustakaan, sistem informasi tersebut dinamakan sistem informasi opensource.

Bayangkan jika saja perpustakaan harus membeli software sistem informasi perpustakaan yang belum tentu sesuai dengan kebutuhan perpustakaan itu sendiri sehingga mengakibatkan perpustakaan sangat ketergantungan dengan pengembang software itu sendiri. Berapa besar investasi yang dilakukan oleh perpustakaan sangat tidak berguna bahkan menjadi beban bagi kerumahtanggaan perpustakaan.

Solusi yang tepat pada saat ini apabila perpustakaan ingin mengaplikasikan sistem informasi manajemen perpustakaan adalah menggunakan sistem informasi opensouce, mengapa demikian karena sistem informasi opensource diciptakan untuk memudahkan layanan informasi baik kepada pengguna ataupun kepada pustakawan yang bisa didapatkan secara gratis, baik dari segi kode program (source code) maupun dari segi pengaplikasian sistem informasi perpustakaan itu sendiri. Program dapat digunakan secara gratis, dan setelah program terimplementasi di perpustakaan, pustakawan pun bebas mengubah program sesuai dengan kebutuhan perpustakaan tanpa melanggar hak cipta. Untuk sekarang ini program opensource dengan license dari GPL dan di kembangkan oleh Bagian Humas Kementrian Pendidikan Nasional adalah SENAYAN OPENSOURCE ATAU SLIMS.

\section{METODE}

Beranjak dari tahapan rencana penelitian sebagaimana tergambar di bawah ini, keseluruhan tahapan dalam penelitian ini dapat dijabarkan sebagai berikut: (1) studi kepustakan (bibliografi research), untuk menemukan filosofis dan teori-teori mengenai pengembangan produk dan implementasi Sistem, (2) analisis kebutuhan sistem dengan beberapa produk open sorce yang akan di gunakan (3) installasi sistem dan pengembangan sesuai 
dengan kebutuhan perpustakaan Undiksha, (4) validasi dan evaluasi sistem untuk mencari kelemahan-kelemahan untuk menyempurnakan sistem sesuai dengan kebutuhan, (5) implementasi sistem secara online sehingga dapat memberikan imbas yang lebih luas.

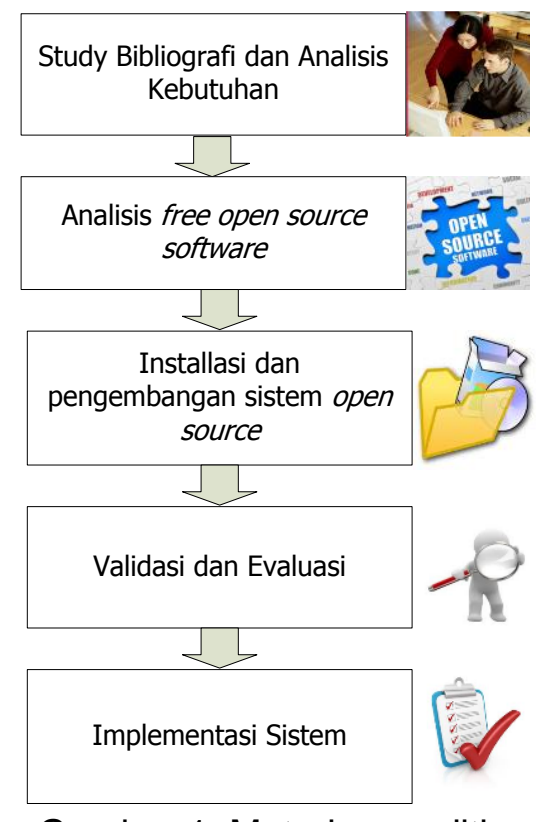

Gambar 1. Metode penelitian

\section{PEMBAHASAN}

\subsection{Profil Senayan}

Senayan merupakan salah satu Free Open Source Software berbasis web yang dapat digunakan sebagai perangkat lunak untuk membangun otomasi perpustakaan. Perangkat lunak berbasis web merupakan perangkat lunak yang sedang naik daun di dunia perpustakaan saat ini. Banyak perpustakaan yang telah menggunakan perangkat lunak jenis ini untuk membangun otomasi perpustakaan atau membangun perpustakaan digital. Beberapa contoh perpustakaan yang menggunakan perangkat lunak berbasis web antara lain Perpustakaan Universitas Indonesia, Perpustakaan di lingkungan Universitas Gadjah Mada, Perpustakaan Institut Teknologi Bandung, Universitas Brawijaya, Malan, Perpustakaan Universitas Sumatera Utara, Perpustakaan Universitas Diponegoro dan masih banyak lagi perpustakaan di Tanah Air yang menggunakan perangkat lunak berbasis web. Pemanfaatan perangkat lunak berbasis web oleh perpustakaan dimotivasi karena aplikasi jenis ini memungkinkan perpustakaan mendekatkan berbagai produk layanannya dengan pengguna perpustakaan. Dengan jenis perangkat lunak ini pengguna dapat mengakses layanan perpustakaan tanpa harus dating ke perpustakaan karena pengguna dapat mengakses layanan yang disediakan perpustakaan melalui web atau portal perpustakaan. Dan jika melihat sistem informasi atau berbagai perangkat lunak yang digunakan saat ini oleh perpustakaan di Tanah Air, banyak perpustakaan yang menggunakan perangkat lunak berbasis web. Senayan dikembangkan dengan menggunakan berbagai perangkat lunak open source. Berbagai perangkat lunak open source yang digunakan untuk mengembangkan Senayan sehingga menjadi sebuah perangkat lunak otomasi perpustakaan, dibedakan menjadi tiga jenis perangkat lunak yaitu perangkat lunak yang berfungsi sebagai web server, bahasa pemrograman dan database. Ketiga perangkat lunak yang digunakan untuk membangun Senayan antara lain Apache sebagai web server, PHP sebagai bahasa pemrograman dan MySQL sebagai database yang menyimpan transaksi data yang terjadi di Senayan. Perangkat lunak ini dibangun dengan menggunakan PHP sehingga kode sumber (source code) perangkat lunak ini bersifat terbuka. Kode sumber yang bersifat terbuka inilah yang memberikan peluang bagi pengguna untuk mengembangkan Senayan lebih lanjut sesuai dengan kebutuhan perpustakaan. $\mathrm{Hal}$ ini dimungkinkan karena PHP merupakan bahasa pemrograman interpreter. Senayan di produksi oleh Pusat Informasi dan Humas Departemen Pendidikan Nasional.

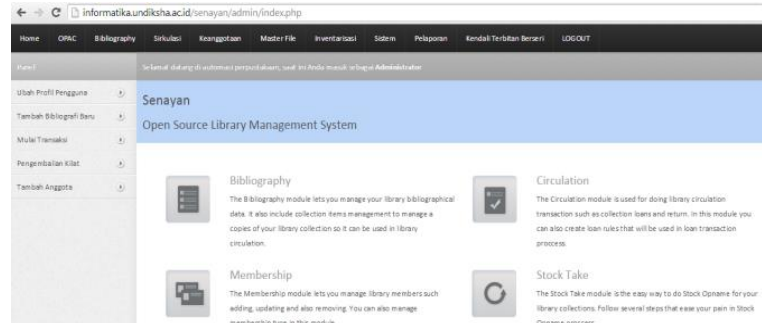

Gambar 2. Tampilan Halaman Admin Senayan Library Managemen System (SLIM) 


\subsection{OPAC (Online Public Acsses Catalog)}

Ketika membuka atau mengoperasikan perangkat lunak ini, maka pertama kali pengguna akan dibawa ke halaman depan perangkat lunak yang berfungsi sebagai OPAC (Online Public Access Catalog). OPAC merupakan menu atau fasilitas yang disediakan untuk pengguna atau pengunjung perpustakaan. OPAC berfungsi sebagai alat bantu bagi pengguna perpustakaan untuk menulusur koleksi yang dimiliki perpustakaan. OPAC sama maknanya dengan katalog online.

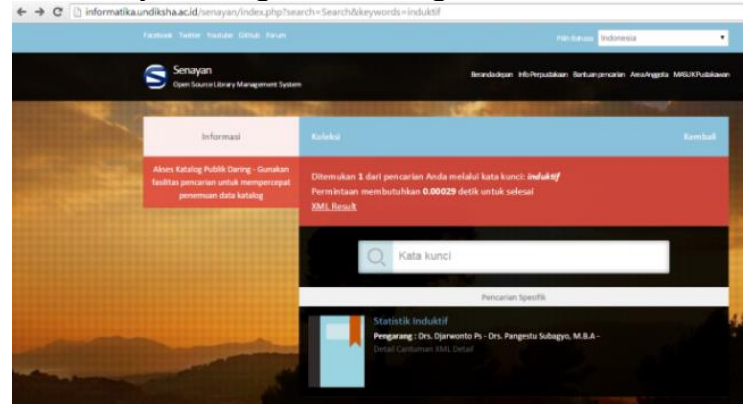

Gambar 3. Tampihan halaman pencarian (OPAC)

\subsection{Bibliography}

Bibliografi merupakan menu yang digunakan untuk melakukan kegiatan pengelolahan koleksi perpustakaan. Melalui menu ini, pustakawan dapat melakukan kegiatan memasukkan data bibliografi koleksi, memasukkan nomor barcode koleksi, editing data bibliografi koleksi, cetak label koleksi, cetak barcode koleksi dan fasilitas import dan eksport data yang sangat bermanfaat dalam kegiatan backup dan migrasi data.

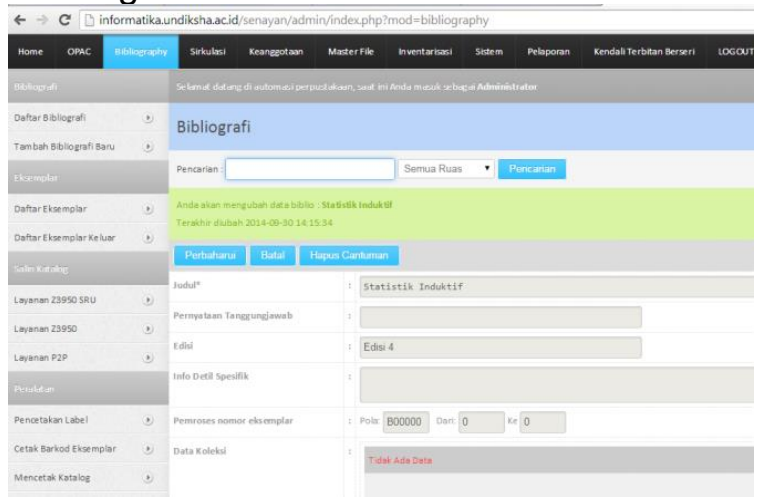

Gambar 4. Tampilan bibliography
Circulation merupakan menu yang gunakan untuk melakukan kegiatan layanan sirkulasi seperti peminjaman, pengembalian, perpanjangan dan memesan koleksi yang sedang dipinjaman oleh penguna lain. Selain itu melalui menu ini pustakawan juga dapat menetapkan aturan peminjaman, sejarah peminjaman dan daftar anggota yang terlambat mengembalikan koleksi yang dipinjam.

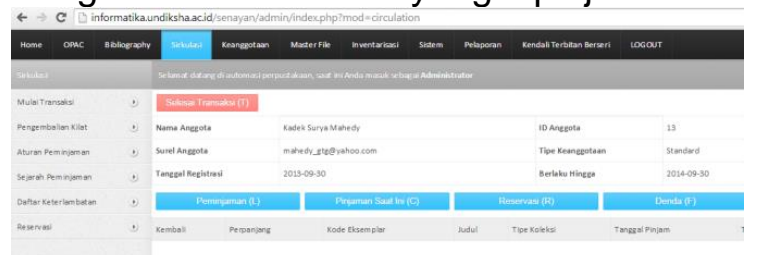

Gambar 5. Tampilan sirkulasi buku

\subsection{Membership}

Membership merupakan menu yang digunakan untuk mendaftarkan anggota atau member perpustakaan. Melalui menu ini pustakawan dapat melakukan input data anggota, mengatur tipe anggota, cetak kartu anggota perpustakaan serta eksport dan import data anggota perpsutakaan

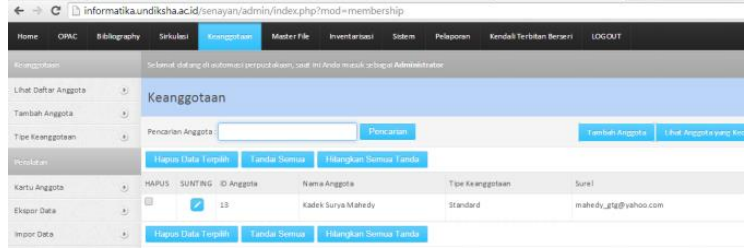

Gambar 6. Tampilan untuk menambahkan member

\subsection{Master File}

Master File merupakan menu yang digunakan untuk menajamen data master seperti data penerbit, pengarang, kota terbit dan subjek. Apabila pengguna Senayan telah mengisi data pengarang, penerbit, kota terbit dan subjek maka ketika pengguna tersebut memasukkan data bibliografi koleksi melalui bibliografi, pengguna tersebut tidak perlu mengetikan nama pengarang, subjek, penerbit dan kota terbit. Pengguna tersebut cukup memilih nama pengarang, penerbit, kota terbit atau subjek

\subsection{Circulation}




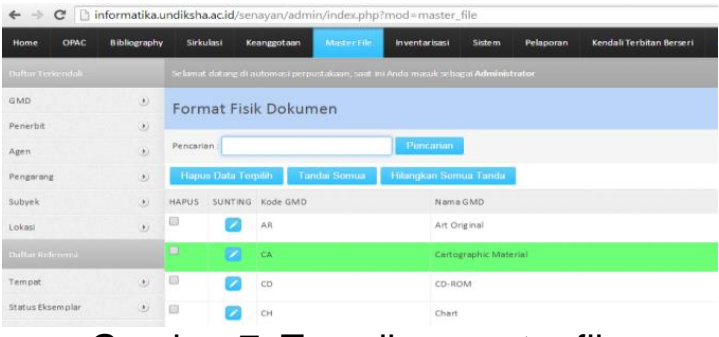

Gambar 7. Tampilan master file

\subsection{Stock Take}

Stock take merupakan menu yang digunakan untuk melakukan kegiatan stock opname. Dengan menggunakan menu ini pengelola perpustakaan berusaha untuk mencocokkan data koleksi yang ada di dalam database Senayan dengan kondisi riil koleksi di rak.

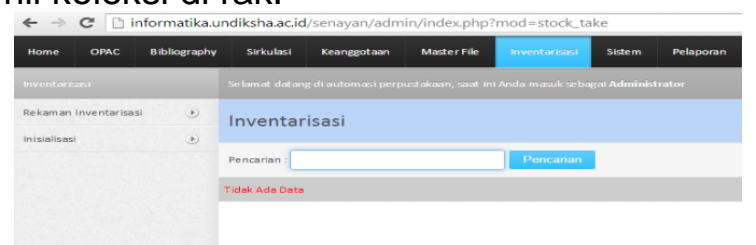

Gambar 8. Tampilan stock take

\subsection{System}

Menu system merupakan menu yan gdisediakan oleh pengembangan Senayan untuk

melakukan kegiatan mengaturan terhadap perangkat lunak secara umum. Dengan menfaatkan menu ini penggunakan dapat membubuhkan identitas perpustakaan, mengatur bahasa pengantar dan melakukan backup database Senayan.

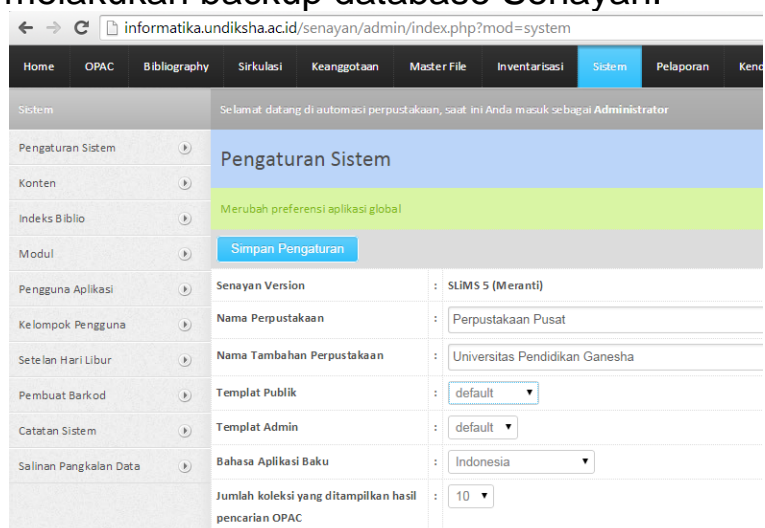

Gambar 9. Tampilan menu system

\subsection{Reporting}

- Berbagai laporan yang disajikan dalam menu reporting antara lain adalah laporan data anggota perpustakaan, data anggota yang terlambat mengembalikan buku, laporan data pengunjung perpustakaan, laporan jumlah koleksi yang dimiliki perpustakaan, laporan transaksi peminjaman, dan pengembalian buku.

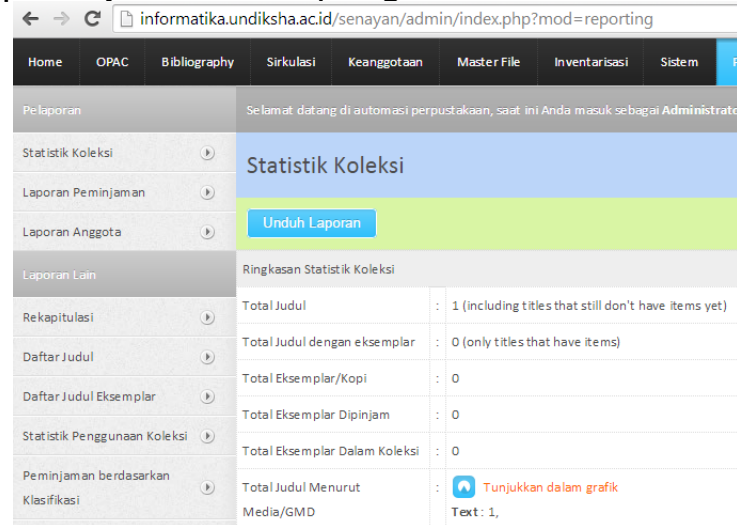

Gambar 10. Tampilan menu laporan

\subsection{Serial Control}

Serial Control merupakan menu yang disediakan untuk melakukan kegiatan pengelolaan koleksi terbitan berkela.

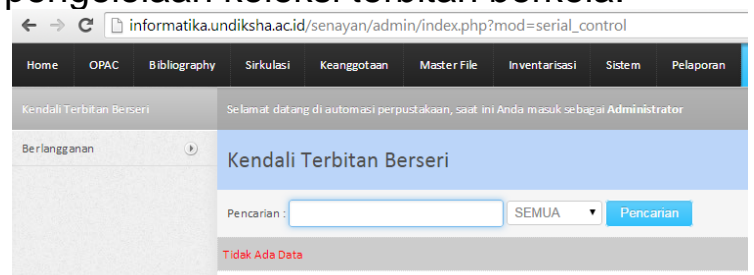

Gambar 11. Tampilan menu serial control

\section{SIMPULAN}

Senayan saat ini merupakan salah free open source software yang dapat diperoleh dan digunakan secara gratis oleh perpustakaan. Namun sebagai free open source software yang dapat diperoleh dan digunakan secara gratis, Senayan tentunya memiliki kelebihan dan kekurangan adapun beberapa kelebihan dari seneyan adalah sebagai berikut.

1. Senayan dapat di unduh dan dikembangkan secara gratis artinya dapat menghemat biaya pengembangan

2. Mampu memenuhi otomasi layanan perpustakaan

3. Senayan merupakan produk local

4. Senayan dikembangkan dengan PHP dan Mysql, bahasa pemrograman yang mudah dipahami sehingga memungkinkan untuk dikembangkan sesuai dengan kebutuhan. 
5. Kompetibel dengan beberapa sistem operasi seperti windows dan linux.

6. Memiliki laporan dan dokumentasi yang sangat lengkap.

Sedangkan kelemahan dari senayan adalah tidak semua web browser mampu menjalankan aplikasi ini dengan sempurna. Perangkat lunak ini merekomendasikan mozilla firefox sebagai web browser. Sehingga jika penggunakan web browser selain mozilla firefox mampu tampilan Senayan tidak akan muncul secara sempurna. Misalnya ada beberapa menu yang akan tertutupi oleh banner jika pengguna menggunakan internet eksplorer sebagai web browser. Tetapi jika hanya digunakan untuk mengakses OPAC (online public access catalog) semua web browser dapat digunakan.

Melalui artikel ini perpustakaan Universitas Pendidikan Ganesha mendapatkan gambaran umum mengenai kelebihan dan kekurangan senayan sebagai sistem otomasi perpustakaan untuk melengkapi kekurangan-kekurangan yang ada pada sistem yang sedang berjalan saat ini.

\section{UCAPAN TERIMA KASIH}

Dalam artikel ini penulis tidak lupa mengucapkan terimakasih kepada pihak perpustakaan Universitas Pendidikan Ganesha yang sudah berkenan meberikan informasi dan data terkait dengan sistem yang ada saat ini.

\section{DAFTAR PUSTAKA}

Bafadal Ibrahim. (2005). Pengelolaan Perpustakaan Sekolah. Jakarta. Bumi Aksara.

Hidayat,R.(2010). Teknologi Wireless RFID Untuk Perpustakaan Polnes : Suatu Peluang. Jurnal Informatika Mulawarman Vol 5 No 1.

Samekta Hadi, R. A. (2008). Implementasi Radio Frequency Identification (RFID) Pada Supply Chain. Konferensi dan Temu Nasional Teknologi Informasi dan Komunikasi untuk Indonesia. Jakarta.
Sanandra, R. (2009). Perancangan Stand Alone RFID Reader untuk Aplikasi Sistem Keamanan Pintu. Retrieved Maret 2012, from Digital library Perpustakaan Pusat Unikom: http://222.124.203.59/gdl.php?mod= browse\&op=read\&id= jbptunikomppgdl-rahmansana19676\&q=Equipment

Senayan Developer Community. Manual Senayan Versi Tiga: Berdasarkan Senayan3-Stable 8. Jakarta, Senayan Developer Community.

SD., D., C, D., \& HK, A. (2010). Sistem Otomasi Perpustakaan Dengan Menggunakan Radio Frequency Identification (RFID). Jurnal Informatika Mulawarman Vol 5 No , 1-7.

Purwoko; Hakim, Heri Abi Burachman dan Surachman, Arif. 2006. "Kajian Awal Aplikasi Open source untuk Otomasi Perpustakaan: Studi Kasus X-igloo, OpenBiblio, Weblis, PhpMyLibrary. Dalam Fihris, Volume 1, Nomor 1.

Want, R. (2006). An Introduction to RFID Technology. the IEEE CS and IEEE ComSoc. 